\title{
Simulation of Streamflows and Basin-Wide Hydrologic Variables over Several Climate-Change Scenarios, Methow River Basin, Washington
}

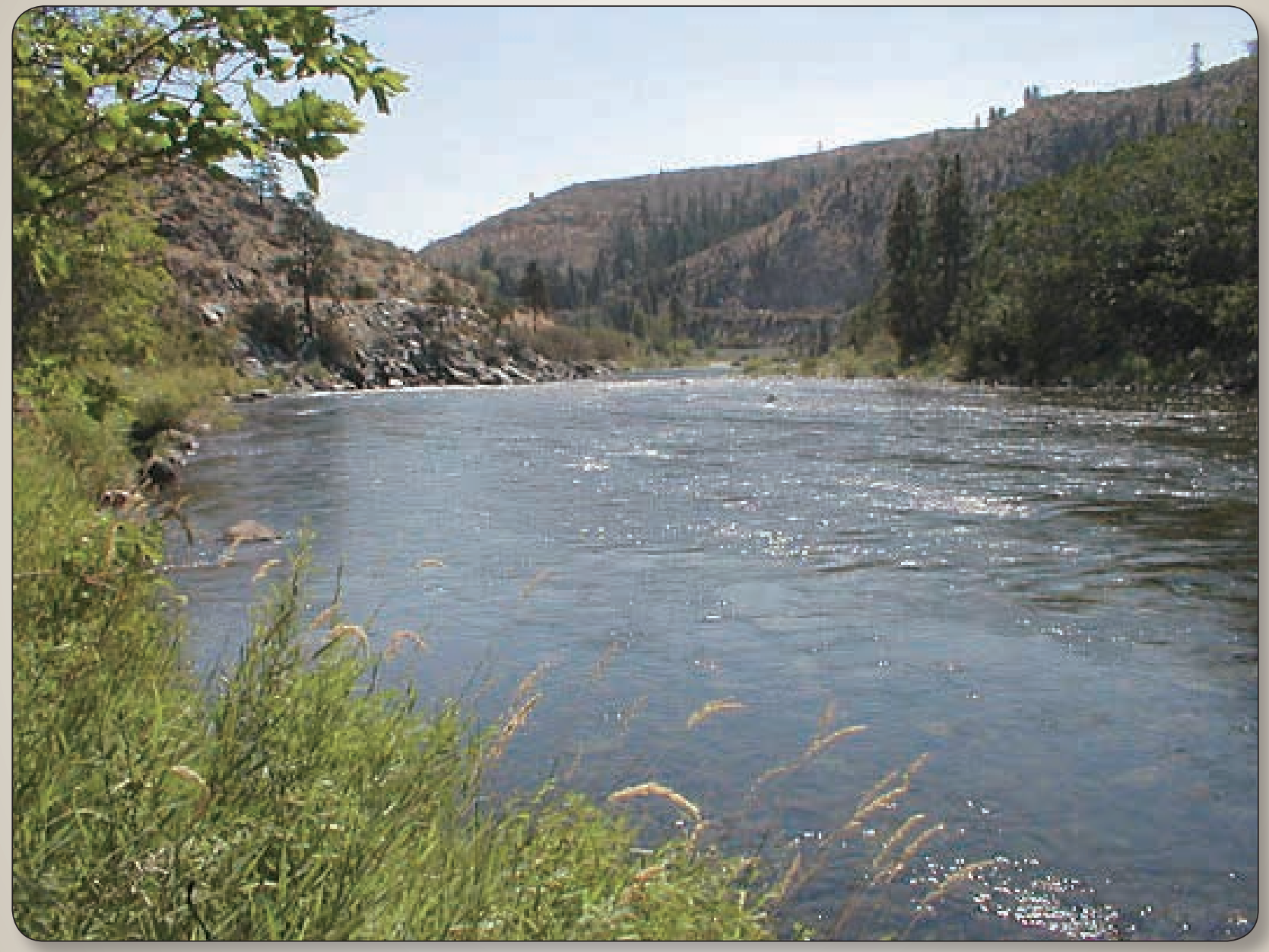

Scientific Investigations Report 2012-5031 
Cover: Photograph of Methow River from U.S. Geological Survey streamflow-gaging station 12449950 near Pateros, Washington. (Photograph taken by U.S. Geological Survey personnel.) 


\section{Simulation of Streamflows and Basin-Wide Hydrologic Variables over Several Climate- Change Scenarios, Methow River Basin, Washington}

By Frank D. Voss and Mark C. Mastin

Scientific Investigations Report 2012-5031 


\title{
U.S. Department of the Interior \\ KEN SALAZAR, Secretary \\ U.S. Geological Survey \\ Marcia K. McNutt, Director
}

\author{
U.S. Geological Survey, Reston, Virginia: 2012
}

For more information on the USGS - the Federal source for science about the Earth, its natural and living resources, natural hazards, and the environment, visit http://www.usgs.gov or call 1-888-ASK-USGS.

For an overview of USGS information products, including maps, imagery, and publications, visit http://www.usgs.gov/pubprod

To order this and other USGS information products, visit http://store.usgs.gov

Any use of trade, product, or firm names is for descriptive purposes only and does not imply endorsement by the U.S. Government.

Although this report is in the public domain, permission must be secured from the individual copyright owners to reproduce any copyrighted materials contained within this report.

Suggested citation:

Voss, F.D., and Mastin, M.C., 2012, Simulation of streamflows and basin-wide hydrologic variables over several climate-change scenarios, Methow River basin, Washington: U.S. Geological Survey Scientific Investigations Report 2012-5031, $18 \mathrm{p}$. 


\section{Contents}

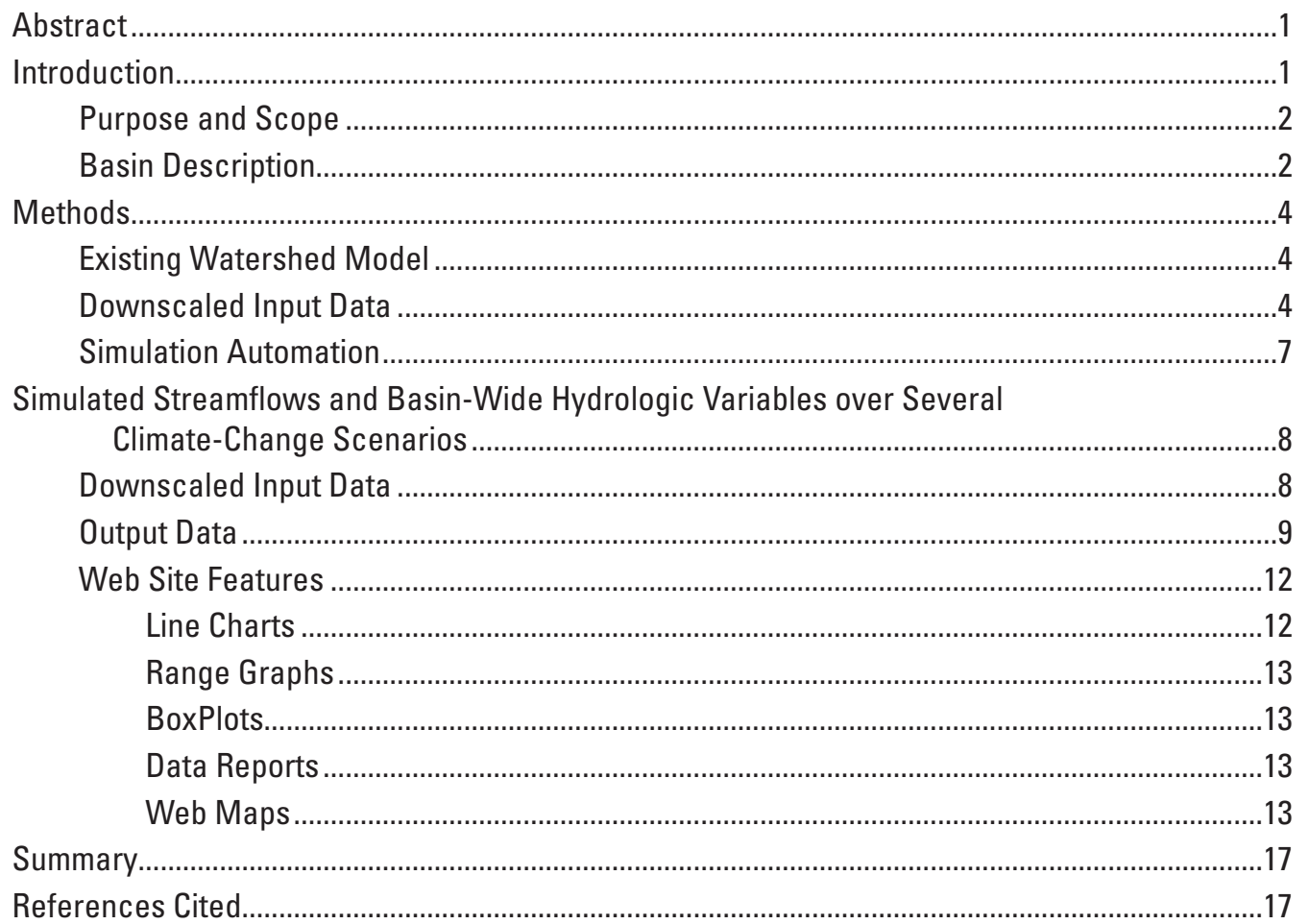

\section{Figures}

Figure 1. Map showing Methow River Basin with U.S. Geological Survey streamflow-gages listed in table 3......

Figure 2. Graph showing mean monthly discharge and range of monthly mean discharges for streamflow-gaging station Methow River near Pateros, Washington, for the complete record, 1959-2010, and for the base period used in this analysis, water years $1990-2000$.

Figure 3. Range plot for PRMS variable daily maximum air temperature (basin_tmax) from 2008 to 2095 showing the central tendencies (averages) and annual mean ranges for five general circulation models and for three greenhouse gas emission scenarios for the Methow River basin, Washington

Figure 4. Range plot for PRMS variable daily average precipitation (basin_ppt) from 2008 to 2095 showing the central tendencies (averages) and annual mean ranges for five general circulation models and for three greenhouse gas emission scenarios for the Methow River basin, Washington

Figure 5. Boxplot for PRMS-simulated averaged daily pack-water equivalent (basin_pweqv) for the basin by month for all general circulation models and greenhouse gas emission scenarios for 11-year windows centered around years 2030, 2060, and 2090 


\section{Figures-Continued}

Figure 6. Boxplot for PRMS-simulated averaged flow on the Methow River at Winthrop, Washington (segment_cfs162) by month all general circulation models and greenhouse gas emission scenarios for 11-year windows centered around years 2030, 2060, and 2090

Figure 7. Line plot for PRMS-simulated average flow for the five different general circulation models for the SRESA2 greenhouse gas emission scenario

Figure 8. Example of the online line graph report for plotting the values of a selected variable for each of the five general circulation models over time for a selected greenhouse gas emission scenario

Figure 9. Example of the online range graph report for graphing selected variables over time

Figure 10. Example of the online boxplot report for generating boxplots representing the distribution of simulated daily values for all the general circulation models and greenhouse gas emission scenario combinations for a g iven month of the year... 15

Figure 11. Example of the online data report for accessing daily values of simulation results for all general circulation models over all greenhouse gas emission scenarios ... 15

Figure 12. Example of the online map report for displaying percent difference in flow between two user-selected years for all simulation sites, for any greenhouse gas emission scenario and general circulation model combination

\section{Tables}

Table 1. General Circulation Model outputs used in this study from the Coupled Model Intercomparison Project Phase 3 (CMIP3) multimodel dataset archive maintained by the World Climate Research Programme

Table 2. Greenhouse gas emission scenarios used in this study from the Intergovernmental Panel on Climate Change (2007)

Table 3. Site information for the 13 U.S. Geological Survey (USGS) streamflow-gaging stations that have simulated flow data in the Precipitation Runoff Modular System (PRMS) output file.

Table 4. General descriptions of the basin-wide variables in the Precipitation Runoff Modular System (PRMS) output file 


\title{
Conversion Factors, Datums, and Abbreviations and Acronyms
}

\author{
Conversion Factors
}

\begin{tabular}{lcl}
\hline \multicolumn{1}{c}{ Multiply } & By & \multicolumn{1}{c}{ To obtain } \\
\hline inch (in.) & Length & \\
inch (in.) & 2.54 & centimeter $(\mathrm{cm})$ \\
foot (ft) & 25.4 & millimeter $(\mathrm{mm})$ \\
mile (mi) & 0.3048 & meter $(\mathrm{m})$ \\
\hline & 1.609 & kilometer $(\mathrm{km})$ \\
\hline square mile $\left(\mathrm{mi}^{2}\right)$ & Area & \\
square mile $\left(\mathrm{mi}^{2}\right)$ & 259.0 & hectare $(\mathrm{ha})$ \\
& 2.590 & square kilometer $\left(\mathrm{km}^{2}\right)$ \\
\hline cubic foot per second $\left(\mathrm{ft}^{3} / \mathrm{s}\right)$ & Flow rate & \\
\hline & 0.02832 & cubic meter per second $\left(\mathrm{m}^{3} / \mathrm{s}\right)$ \\
\hline
\end{tabular}

Temperature in degrees Fahrenheit $\left({ }^{\circ} \mathrm{F}\right)$ may be converted to degrees Celsius $\left({ }^{\circ} \mathrm{C}\right)$ as follows:

$$
{ }^{\circ} \mathrm{C}=\left({ }^{\circ} \mathrm{F}-32\right) / 1.8 \text {. }
$$

Datums

Vertical coordinate information is referenced to the North American Vertical Datum of 1988 (NAVD 88).

Horizontal coordinate information is referenced to the North American Datum of 1983 (NAD 83).

Elevation, as used in this report, refers to distance above the vertical datum.

Abbreviations and Acronyms

$\begin{array}{ll}\text { GCM } & \text { General circulation model } \\ \text { GSFLOW } & \text { Ground-water and surface-water flow model } \\ \text { HRU } & \text { Hydrologic response units } \\ \text { MMS } & \text { Modular modeling system } \\ \text { MRU } & \text { Model response unit } \\ \text { PRMS } & \text { Precipitation Runoff Modeling System } \\ \text { SSIS } & \text { SOL Server Integration Services } \\ \text { USGS } & \text { U.S. Geological Survey }\end{array}$


This page intentionally left blank 


\title{
Simulation of Streamflows and Basin-Wide Hydrologic Variables over Several Climate-Change Scenarios, Methow River Basin, Washington
}

\author{
By Frank D. Voss and Mark C. Mastin
}

\section{Abstract}

The purpose of this project was to demonstrate the capabilities of an existing watershed model and downscaling procedures to provide simulated hydrological data over various greenhouse gas emission scenarios for use in the Methow River framework prototype. An existing watershed model was used to simulate daily time series of streamflow and basin-wide hydrologic variables for baseline conditions (1990-2000), and then for all combinations of three greenhouse gas emission scenarios and five general circulation models for future conditions (2008-2095). Input data for 18 precipitation and 17 temperature model input sites were generated using statistical techniques to downscale general circulation model data. The simulated results were averaged using an 11-year moving window to characterize the central year of the window to provide simulated data for water years 2008-2095.

Simulation results indicate that substantial changes of monthly mean streamflows will occur. For all greenhouse gas emission scenarios, the future streamflows are greater in the winter than baseline conditions because a greater percentage of future precipitation is projected to fall as rain rather than as snow. The simulated future spring streamflows are less than baseline conditions because the spring snowpacks are smaller; therefore, flow contributions from snowmelt are less.

A database was developed to automate model execution and to provide users with Internet access to voluminous data products ranging from summary figures to model output timeseries. Database-enabled Internet tools were developed to allow users to create interactive graphs of output results based on their analysis needs. For example, users were able to create graphs by selecting time intervals, greenhouse gas emission scenarios, general circulation models, and specific hydrologic variables.

\section{Introduction}

The U.S. Geological Survey (USGS) and the National Oceanic and Atmospheric Administration's National Weather Service are currently testing frameworks for compiling and organizing data and scientific information to support local and regional climate-related decision making. A decisionanalysis framework (Kiker and others, 2005) prototype for addressing future water-availability issues was developed for the Methow River basin. The prototype uses streamflow simulations generated by the University of Washington's Climate Impact Group for the Columbia River Basin (Hamlet, 2010) for six streamflow sites in the Methow River basin. However, these six streamflow sites are near the mouths of the rivers and do not represent streamflow in the small watersheds in the Methow River basin. In discussions with the local stakeholders, it was apparent more streamflow information is needed in the small watersheds where many restoration activities have been targeted.

To address the problem of limited simulated streamflow data, two existing USGS studies were combined to produce more detailed hydrologic data for the Methow River basin framework prototype: (1) a surface-water study that developed a watershed model of the Methow River basin with the Precipitation Runoff Modeling System (PRMS) (Ely, 2003); and (2) a climate-change study by the USGS National Climate Change Project (Hay and others, 2011) that developed techniques for downscaling data from large-scale climate models for input to PRMS. 


\section{Purpose and Scope}

The purpose of this project was to demonstrate the capabilities of an existing watershed model and downscaling procedures to provide simulated hydrologic data over various greenhouse gas emission scenarios for use in the Methow River framework prototype. It was also our purpose to develop an Internet-based tool to provide stakeholders with the capability of interactively creating and downloading their own customized graphs of simulation results and an interactive analysis tool with user-friendly menus to allow users to select and download simulated hydrology data to meet their specific needs.

The scope of the modeling work consisted of simulating daily values for flow at 13 streamflow-gaging stations in the Methow River basin and for 10 basin-wide hydrologic variables using 15 combinations of three greenhouse gas emission scenarios and five general circulation models over an 87-year period [water years 2008-2095]. The watershed model provides simulated daily streamflow at more sites and for more basin-wide hydrologic variables, however, the variables presented in this report provide a view into the capabilities of the model.

\section{Basin Description}

The Methow River drains a 1,820-mi² area basin (U.S. Geological Survey, 2011) located in north-central Washington on the east side of the Cascade Mountains (fig. 1). The river flows south or southeast from peaks along the Cascade crest ranging as high as 8,950 $\mathrm{ft}$ in elevation to the town of Pateros at the mouth of the river where it feeds the Columbia River at an elevation of $775 \mathrm{ft}$. The climate varies from alpine conditions in the headwaters that receive up to $80 \mathrm{in}$. of precipitation per year (mostly in the form of snow) to the semi-arid lowlands that receive about 10 in. of precipitation per year. The average annual precipitation for the basin is 31.9 in. (U.S. Geological Survey, 2011).

Water availability in the Methow River basin is vital for sustaining the local economy and the fragile ecosystem. Irrigation for agriculture accounts for 99 percent of the allocated water use as determined from water rights (Methow Basin Planning, 2005). In 2000, the basin contained 16,730 acres of irrigated land, 77 percent of which were planted in alfalfa, and the remaining acreage primarily was orchards or pasture. Seepage from river channels, irrigated farmland, and unlined irrigation ditches recharge groundwater reservoirs (Konrad and others, 2003) that provide groundwater discharge necessary for maintaining wetlands, riparian habitat, and flows during the late summer and fall. These summer and fall flows are vital for supporting the Upper Columbia summer steelhead and spring Chinook salmon populations (which are both listed as endangered under the Endangered Species Act), as well as bull trout populations (listed as a threatened species). Water also is important for the growing tourism industry, which includes Nordic skiing, fishing, boating, and wildland recreation. Long-term planning that includes the impacts of potential climate change on the water resources is necessary for managing these competing water demands. 


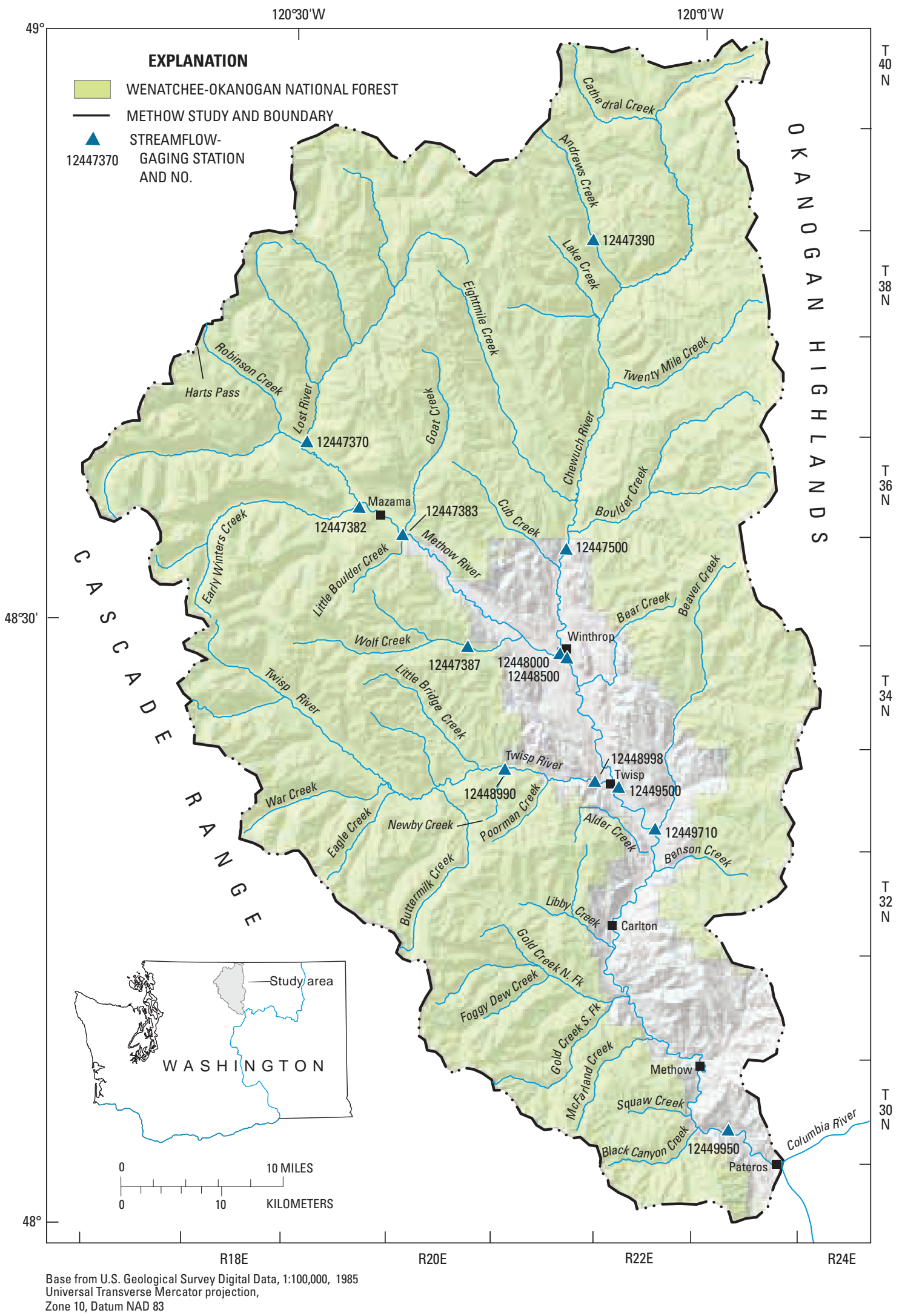

Figure 1. Methow River Basin with U.S. Geological Survey streamflow-gages listed in table 3. 
Simulation of streamflows and hydrologic variables over climate-change scenarios, Methow River basin, Washington

\section{Methods}

The existing watershed model and existing downscaling procedure that are described in detail in the referenced sources also were used in the present study, but are only briefly described in this report. The automation of the runoff simulations discussed in this section and the development of an Internet database for data extraction, tabulation, and display originated from this project.

\section{Existing Watershed Model}

The watershed model constructed for the Methow River basin by Ely and Risley (2001) and updated by Ely (2003) is a Precipitation Runoff Modular System (PRMS) watershed model that operates under the Modular Modeling System (MMS) (Leavesley and others, 1996). The model runs on a daily time step and requires as input daily precipitation and maximum and minimum daily air temperature. The basin is partitioned into hydrologic response units (HRUs), which are sometimes referred to as model response units (MRUs) or units of land that have similar hydrologic responses to moisture and temperature inputs. A water budget is calculated for each HRU to estimate surface, subsurface, and groundwater outflow. Flow-routing segments (previously called nodes) accumulate simulated flow and provide daily totals to the user as output. The PRMS model is more thoroughly described by Leavesley and others (1983).

The Methow River basin watershed model contains 620 HRUs and 211 flow-routing segments. HRUs were delineated using a digital elevation model to create a simulated streamflow network. The GIS Weasel (a computer program developed by Viger and others, 1998) delineated the first set of HRUs using a two flow-plane algorithm that created two flow-plane subbasins for each segment. The HRUs were then further subdivided into elevation bands at 1,000-foot intervals to account for hydrological response differences that occur with elevation. The minimum HRU size was set at $1 \mathrm{mi}^{2}$. Daily records at 18 precipitation stations and 17 air temperature stations provide input to the watershed model. Precipitation is distributed to the HRUs using a weighting scheme that uses the inverse of the square of the distance between a weather station and an HRU and the ratio of mean monthly precipitation at the HRU to the mean monthly precipitation at the recording station. HRU mean monthly precipitation was computed for a PRISM model that used mean monthly recorded precipitation for 1961-1990 (Daly and others, 1994). Air temperatures are distributed to the HRUs using all station data and a similar inverse-distance weighting scheme as the precipitation distribution and then adjusting the value with a calculated daily lapse rate from the weather station data.

The watershed model includes the simulation of diversions, irrigation canal losses, and application rates as implemented by Ely (2003) for the period beginning May 1 and ending October 7 for each year of simulation. This includes 16 diversions following the schedule outlined in Ely (2003, table 3) that ranged from $1.5 \mathrm{ft}^{3} / \mathrm{s}$ (October 1-7, McKinney Mountain) to a maximum of $42 \mathrm{ft}^{3} / \mathrm{s}$ (July, MVID East). The seepage rate of diverted water in the irrigation canals is simulated at 50 percent of the total flow for all diversions, and then directed to a selected groundwater reservoir that is contained within a HRU. Application rates were set to $0.2 \mathrm{in} / \mathrm{d}$ for selected MRUs for May 1-October 7 . This is equivalent to $32 \mathrm{in}$. of water for the irrigation season, the average annual water requirement for alfalfa (Ely, 2003). These diversions, canal losses, and application rates are estimates of the current conditions and may or may not reflect future conditions. Diversions of water for irrigation probably will continue in the future, and the current estimates were considered a reasonable estimate of future irrigation practices.

The original model simulations of annual mean streamflow as a percentage of measured annual mean streamflow for the 10-year calibration period (water years 1992-2001) at six of the seven streamflow-gaging stations ranged from -35.2 to +26.2 percent, with 65 percent of the simulated values within 15 percent (Ely, 2003).

The model, originally developed to run on a UNIX operating system, has been updated to run on a Microsoft Windows ${ }^{\circledR}$ operating system. The code also has been updated to accommodate GSFLOW, a coupled Groundwater and Surface-water flow model that uses PRMS for the surfacewater algorithms (Markstrom and others, 2008). The updated model included changes in several parameter names and slight alteration of the algorithms. As a result, the simulations with the old and new models do not match exactly. There were subtle differences in simulated streamflow computed with the old and new models at locations that coincide with 11 USGS streamflow-gaging stations in the Methow River basin for water years 1960-2001. The simulated mean annual streamflow for the current application was within 5 percent of the earlier simulation (Ely, 2003) for all sites except for Beaver Creek (station 12449710), which was 8.8 percent different.

\section{Downscaled Input Data}

As part of a national USGS Global Climate Change study, hydrologic responses to potential climate change were created for 14 different watersheds across the United States (Hay and others, 2011). General circulation model (GCM) data were downscaled to selected climate station locations using a 'climate change factor' or 'delta change' method (Hay and others, 2000; Diaz-Nieto and Wilby, 2005). A climate-change factor is a percentage change for precipitation and degree change for air temperature applied to the monthly mean values for a base period of observed values. This study for the Methow River basin followed the methodology of climate-change analysis, including the USGS national study's selection of GCMs and emission scenarios, to allow the results 
to be directly comparable with the national study results and leverage the work that had already been done to complete the national study.

The USGS national study identified five general circulation models (table 1) with archived output available at the World Climate Research Programme's Coupled Model Intercomparison Project Phase 3 (CMIP3) and three greenhouse gas emission scenarios (table 2) that could be used by the PRMS models. The three greenhouse gas emission scenarios represent different projections of future greenhouse concentrations, reflective of economic and population growth rates, and technological efficiency. The greenhouse gas concentrations range from relatively low (B1), to medium (A1B), and to high concentrations (A2) (Intergovernmental Panel on Climate Change, 2007). The baseline period for the national study was water years 1989-2000. Computer scripts used for downscaling GCM output to PRMS input for the national study were used to downscale the same GCM output to the 18 precipitation and 17 temperature inputs sites used by the Methow River basin PRMS watershed model.

Mean monthly percentage changes in precipitation, degree changes in temperature, and climate-change factors were computed from the output of each general circulation model for each of the three greenhouse gas emission scenarios for each of the Methow model input weather sites. The climate-change factors were applied to each of the daily values for each station using the change factor from the closest general circulation model grid node. These climate change factors were applied to the input data for the base conditions for water years 1988-2000. Because the initial values of the

Table 1. General Circulation Model outputs used in this study from the Coupled Model Intercomparison Project Phase 3 (CMIP3) multimodel dataset archive maintained by the World Climate Research Programme.

[CMIP3 general circulation model documentation, references, and links can be accessed at http://www-pcmdi.llnl.gov/ipcc/model documentation/ipcc model documentation.php]

\begin{tabular}{ll}
\hline $\begin{array}{c}\text { General } \\
\text { circulation } \\
\text { model }\end{array}$ & \multicolumn{1}{c}{ Description } \\
\hline BCCR-BCM2.0 & Bjerknes Centre for Climate Research, Norway \\
CSIRO-Mk3.0 & $\begin{array}{c}\text { Australia's Commonwealth Scientific and } \\
\text { Industrial Research Organisation, Australia }\end{array}$ \\
CSIRO-Mk3.5 & Australia's Commonwealth Scientific and \\
& Industrial Research Organisation, Australia \\
INM-CM3.0 & $\begin{array}{c}\text { Institute for Numerical Mathematics, Russia } \\
\text { MIROC3.2 }\end{array}$ \\
& Japanal Institute for Environmental Studies, \\
\hline
\end{tabular}

model variables are not known, the first 2 years are used to "warm up," or initialize, the model prior to the time of interest; therefore, the base conditions period is actually for water years 1990-2000.

Future scenarios of runoff are based on monthly change factors to the base conditions and will mimic the hydrology represented by the base period for water years 1990-2000. This period is similar to the mean monthly discharges of the long-term record (1959-2010) at the streamflow-gaging station near the mouth of the river, but some of the extremes are not represented in this base period (fig. 2).

The 1988-2000 PRMS input file with the recorded station data was modified with the monthly climate-change factors derived from each general circulation model/greenhouse gas emission scenario combination to create 11-year moving windows of input data files to simulate the possible future streamflow time series with the PRMS model. The 11-year moving windows begin in 2001 and end in 2099, resulting in 1,320 greenhouse gas emission scenarios ([eighty-eight 11-year moving windows-one per year from 2001-2012 to 2088-2099] × [3 greenhouse gas emission scenarios] × [5 general circulation models]).

Twenty-one variables were selected to be output from the model, 13 of which are segment variables with simulated streamflow that correspond to 13 USGS-operated streamflowgaging stations in the basin and 10 basin-wide variables (tables 3 and 4). Other variables could have been selected for the model runs made for this report, and the modeling process repeated to obtain data for other sites or other hydrologic variables not included in this set.

Table 2. Greenhouse gas emission scenarios used in this study from the Intergovernmental Panel on Climate Change (2007).

\begin{tabular}{|c|c|}
\hline $\begin{array}{l}\text { Greenhouse gas } \\
\text { emission scenario }\end{array}$ & Description/assumptions \\
\hline SRESA1B & $\begin{array}{l}\text { Very rapid economic growth, a global population } \\
\text { that peaks in mid-21st century and rapid } \\
\text { introduction of new and more efficient } \\
\text { technologies with a balanced emphasis on all } \\
\text { energy sources. }\end{array}$ \\
\hline SRESB1 & $\begin{array}{l}\text { Convergent World, with the same global } \\
\text { population as greenhouse gas emission } \\
\text { scenario SREA1B, but with more rapid } \\
\text { changes in economic structures toward a } \\
\text { service and information economy that is more } \\
\text { ecologically friendly. }\end{array}$ \\
\hline SRESA2 & $\begin{array}{l}\text { Very heterogeneous World with high population } \\
\text { growth, slow economic development, and slow } \\
\text { technological change. }\end{array}$ \\
\hline
\end{tabular}




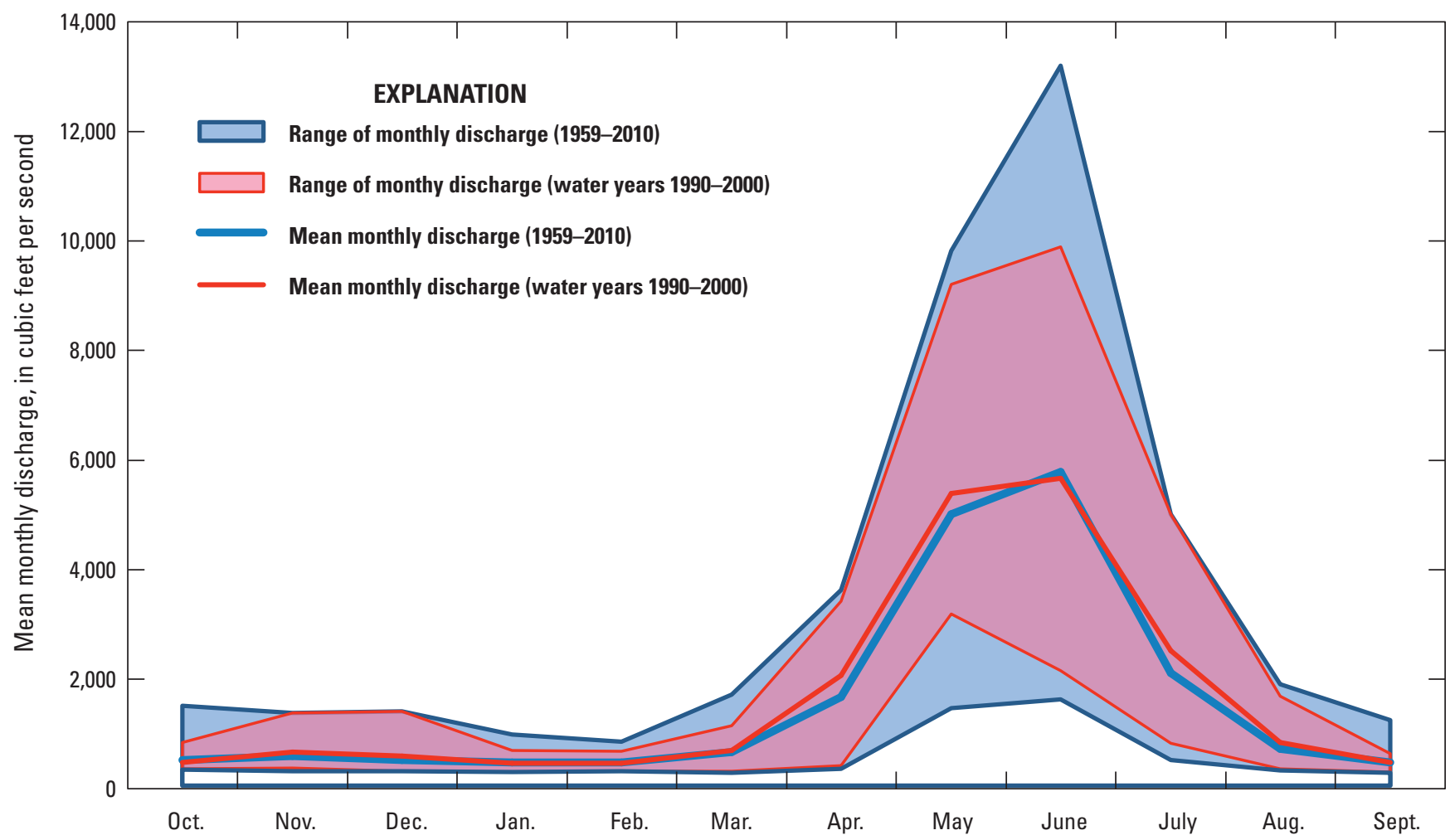

Figure 2. Mean monthly discharge and range of monthly mean discharges for streamflow-gaging station Methow River near Pateros, Washington, for the complete record, 1959-2010, and for the base period used in this analysis, water years 1990-2000.

Table 3. Site information for the 13 U.S. Geological Survey (USGS) streamflow-gaging stations that have simulated flow data in the Precipitation Runoff Modular System (PRMS) output file.

\begin{tabular}{|c|c|c|}
\hline $\begin{array}{c}\text { PRMS } \\
\text { Segment No. }\end{array}$ & $\begin{array}{c}\text { USGS } \\
\text { station No. } \\
\text { (see fig. 1) }\end{array}$ & Station name \\
\hline segment_cfs 10 & 12447370 & Lost River near Mazama \\
\hline segment_cfs 20 & 12447382 & Early Winters Creek near Mazama \\
\hline segment_cfs 148 & 12447383 & $\begin{array}{l}\text { Methow River above Goat Creek, } \\
\text { near Mazama }\end{array}$ \\
\hline segment_cfs 35 & 12447387 & $\begin{array}{l}\text { Wolf Creek below diversion, near } \\
\text { Winthrop }\end{array}$ \\
\hline segment_cfs 41 & 12447390 & Andrews Creek near Mazama \\
\hline segment_cfs 80 & 12447500 & Chewuch River below Boulder Creek \\
\hline segment_cfs 88 & 12448000 & Chewuch River at Winthrop \\
\hline segment_cfs 162 & 12448500 & Methow River at Winthrop \\
\hline segment_cfs 100 & 12448990 & $\begin{array}{l}\text { Twisp River above Newby Creek, } \\
\text { near Twisp }\end{array}$ \\
\hline segment_cfs 111 & 12448998 & Twisp River near Twisp \\
\hline segment_cfs 172 & 12449500 & Methow River near Twisp \\
\hline segment_cfs 124 & 12449710 & Beaver Creek near mouth, near Twisp \\
\hline segment_cfs 204 & 12449950 & Methow River near Pateros \\
\hline
\end{tabular}

Table 4. General descriptions of the basin-wide variables in the Precipitation Runoff Modular System (PRMS) output file.

[All variables are area-weighted adjusted average daily values]

\begin{tabular}{|c|c|}
\hline $\begin{array}{l}\text { PRMS } \\
\text { basin variable }\end{array}$ & Description of variable \\
\hline basin_et & $\begin{array}{l}\text { Evapotranspiration, including } \\
\text { evapotranspiration, snow evaporation, and } \\
\text { interception evaporation, in inches, for the } \\
\text { basin }\end{array}$ \\
\hline basin_ppt & Precipitation, in inches, for the basin. \\
\hline basin_pweqv & $\begin{array}{l}\text { Snowpack water equivalent, in inches, for the } \\
\text { basin. }\end{array}$ \\
\hline basin_snowcov & $\begin{array}{l}\text { Snow cover as a percentage of HRUs with } \\
\text { simulated snow for the basin. }\end{array}$ \\
\hline basin_soil_moist & Soil moisture, in inches, for the basin. \\
\hline basin_sroff & Surface outflow, in inches, for the basin. \\
\hline basin_ssflow & Subsurface outflow, in inches, for the basin. \\
\hline basin_storage & $\begin{array}{l}\text { Storage, including groundwater, subsurface } \\
\text { storage, soil moisture, snowpack, and } \\
\text { interception, in inches, for the basin. }\end{array}$ \\
\hline basin_tmax & $\begin{array}{l}\text { Maximum air temperature, in degrees } \\
\text { Fahrenheit, for the basin. }\end{array}$ \\
\hline basin_tmin & $\begin{array}{l}\text { Minimum air temperature, in degrees } \\
\text { Fahrenheit, for the basin. }\end{array}$ \\
\hline
\end{tabular}




\section{Simulation Automation}

SQL Server 2008 R2 programming tools were used to develop a software system for creating input and executing the model for 1,320 model runs, storing output data and processing simulation results for all these runs, and making project data available on the Internet. The system was designed to do the following:

- Execute 1320 model runs in series. Simulating all general circulation model, greenhouse gas emission scenarios, and 11-year moving window combinations can result in a large number of runs. For this study, 1,320 runs were needed, but the system is designed so that many different combinations of additional greenhouse gas emission scenarios and general circulation models can be used to simulate future hydrologic conditions.

- Process large numbers of records. Model runs produce a large amount of output data (for this study, more than 127 million records were processed). An application was developed for processing simulation results and storing them in a relational database.

- Provide stakeholders with many output variable options for analyzing data. The model has a large number of output variables. The system was designed so that different combinations of variables could be selected for output without having to alter program code.

- Provide public Internet access to data and analysis products. Because one goal of this project was to have stakeholders use simulation data for planning, a Web site was developed to provide access to all data in the project database.

The system uses a database-driven approach for automating model runs and processing simulation results. The term "database-driven" means that the user controls processing by changing data in a database rather than to the input files and programs that access the data. For example, using a database-driven approach, a user can determine the number of greenhouse gas emission scenarios and general circulation models to be run by adding configuration data to the database. A database-driven model automation program was developed to use this configuration data to detect and run all the greenhouse gas emission scenarios in the database without any additional user input. A goal of the databasedriven approach is to minimize the need for a user to perform manual operations (such as copying files, cutting and pasting data, or altering computer code) and thereby reduce user error, produce consistent results, and make operations easier.

SQL Server 2008 R2 Management Studio was used to develop a single relational database for storing and managing all project data. All tables in the database were normalized to ensure that the database structure was suitable for efficient querying and to reduce insert, update, and deletion errors that could corrupt data.

Using one relational database had many advantages over using text files and spreadsheets stored in directories. A consistent data storage system made querying and managing data easier than it would be if the data were stored in assorted files with various file formats in multiple directories. Data security was enhanced because the database was protected by selectively setting permissions and passwords to limit access to the data to appropriate users. Data integrity was maintained by setting constraints on data to ensure unwanted values were not permitted in the data tables (such as unplanned null values or values that exceed user-specified ranges). This reduced the likelihood of erroneous values being used for model input or analysis. The database is scalable, which means the number of records in the data tables can be increased without changing database structure. Therefore, the same database can be used to run simulations at the local, state, or regional scale. Built-in database analysis tools made it possible to perform complex queries and can be used for future studies to perform data mining to explore trends and relationships between model input and output data. Most importantly, the database is adaptable to many types of analysis tasks, which present many options for future work. For example, the database can be linked to other deterministic models or used for statistical or data mining studies. The database also can be linked with other data sources to provide information to the public through the Internet.

The SQL Server Integration Services (SSIS), a development tool within SQL Server 2008 R2, was used to develop applications (also called solutions) for running simulations and processing simulation results. SSIS was selected because of its tools for extraction, loading, and transformation (ELT) of data, and for its capability to read data from, and write data to, a wide variety of data storage formats (such as databases, delimited text files, and spreadsheets), which will facilitate integrating the watershed model with decision support systems. A SSIS solution consists of a set of integrated modular subprograms (called packages) that are programmed to perform specific tasks. SSIS graphical tools were used to develop a program framework. C\#.NET and SQL code was then written for performing customized complex data manipulation tasks.

To summarize, 1,320 model runs were completed to simulate all combinations of three greenhouse gas emission scenarios, five general circulation models, and eighty-eight 11-year moving windows. More than 127 million records were processed over a 50-hour period to produce a 1-GB database storing daily, monthly, and central year values for 21 output variables. All output data from the simulations are stored in a relational database that is accessible to the public via the Internet. 


\section{Simulated Streamflows and Basin- Wide Hydrologic Variables over Several Climate-Change Scenarios}

PRMS streamflow simulation results were analyzed by comparing mean monthly and annual values from input generated by the GCMs and greenhouse gas emission scenarios. Analysis at a smaller time step was not appropriate because input data for the simulations were generated by applying monthly adjustments to daily data from the baseline period (water years 1990-2000). Therefore, each time period used for the simulations has the same underlying daily temporal pattern of the baseline period but with different daily and monthly mean values.

\section{Downscaled Input Data}

In this study, two variables (basin_tmax and basin_ppt) are area-weighted adjusted averaged data for the basin computed from the individual HRU tmax and ppt data distributed by the model from the downscaled station data. The range graphs created using the model output show the range and central tendency of the variable.

The central tendency is the mean of the mean annual values of an 11-year window for the five general circulation models computed for each greenhouse gas emissions scenario. This mean is assigned to the central year of the moving 11-year window; for example, the central year for the 20012013 11-year window is 2008 (first 2 years of any 13-year window are used to stabilize or "warm-up" the model and are not used for the range or mean calculations). The range represents the range of mean annual values for the five general circulation models for each greenhouse gas emission scenario.
The central tendencies and ranges in the daily maximum air temperature (basin_tmax) show an upward trend for all greenhouse gas emission scenarios in the range graph (fig. 3). Applying linear regression to the average values for each greenhouse gas emission scenario results in a range of slope coefficients for the linear equation from 0.0432 to 0.0633 , indicating a trend of increasing air temperature over time and adjusted R-square values ranging from 0.974 to 0.987 . The adjusted R-square values account for the lag- 1 autocorrelation on the degrees of freedom (McCabe and Wolock, 1997). The range plot for basin_tmax (and in a similar manner for basin tmin) shows a gradual warming with the biggest temperature average increase between 2008 and 2095 equal to $5.42^{\circ} \mathrm{F}$ for the SRESA2 greenhouse gas emission scenarios and smallest temperature increase equal to $3.33^{\circ} \mathrm{F}$ for the SRESB1 greenhouse gas emission scenarios.

The central tendencies and ranges in daily average precipitation (basin_ppt) show more variability than the central tendencies and ranges in air temperature for the three greenhouse gas emissions scenarios (fig. 4). All greenhouse gas emission scenarios show an increase in precipitation from the beginning of the simulated period to the end; however, the increase for the SRESB1 greenhouse gas emission scenario is very slight, from 0.095 to $0.097 \mathrm{in}$., reflecting a 2.1 percent increase. The other greenhouse gas emission scenarios increased more-9.8 percent for the SRESA1B greenhouse gas emission scenario, and 14.3 percent for SRESA2 greenhouse gas emission scenario. The precipitation trend is much less evident than the air temperature trend. Slope coefficients for the linear regression with precipitation range from 0.000030 to 0.000114 with adjusted R-square values of 0.2984 (SRESB1) to 0.8469 (SRESA2).

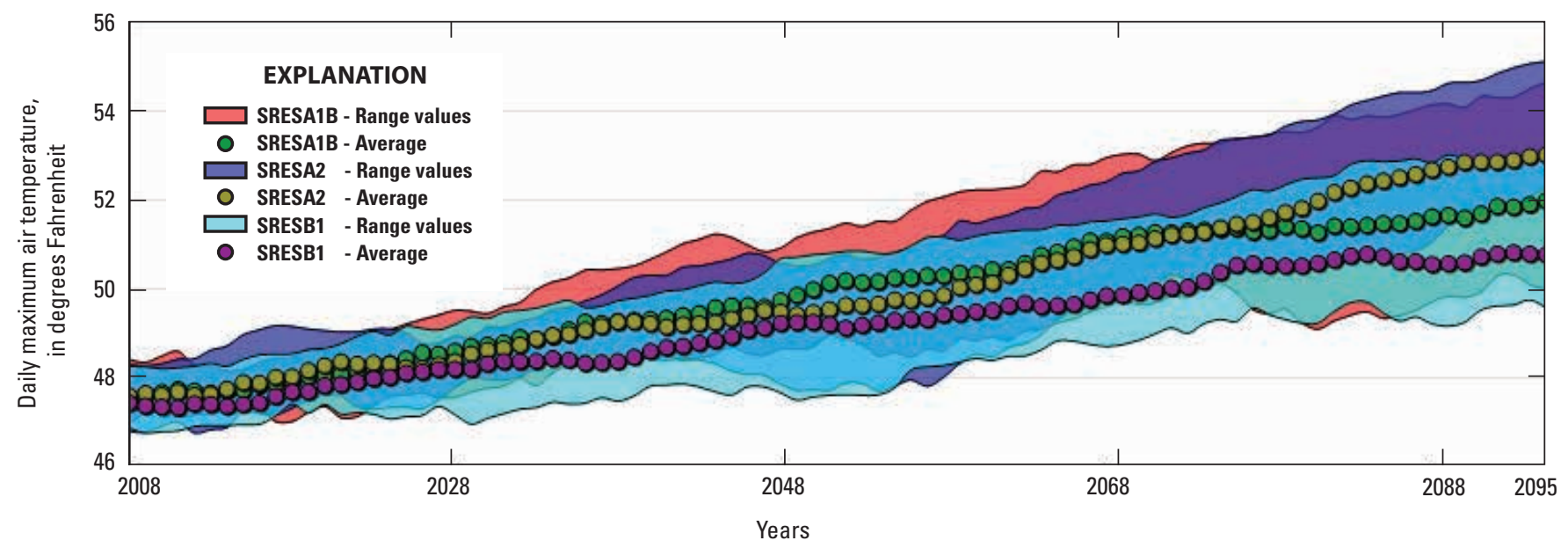

Figure 3. Range plot for PRMS variable daily maximum air temperature (basin_tmax) from 2008 to 2095 showing the central tendencies (averages) and annual mean ranges for five general circulation models and for three greenhouse gas emission scenarios for the Methow River basin, Washington. 


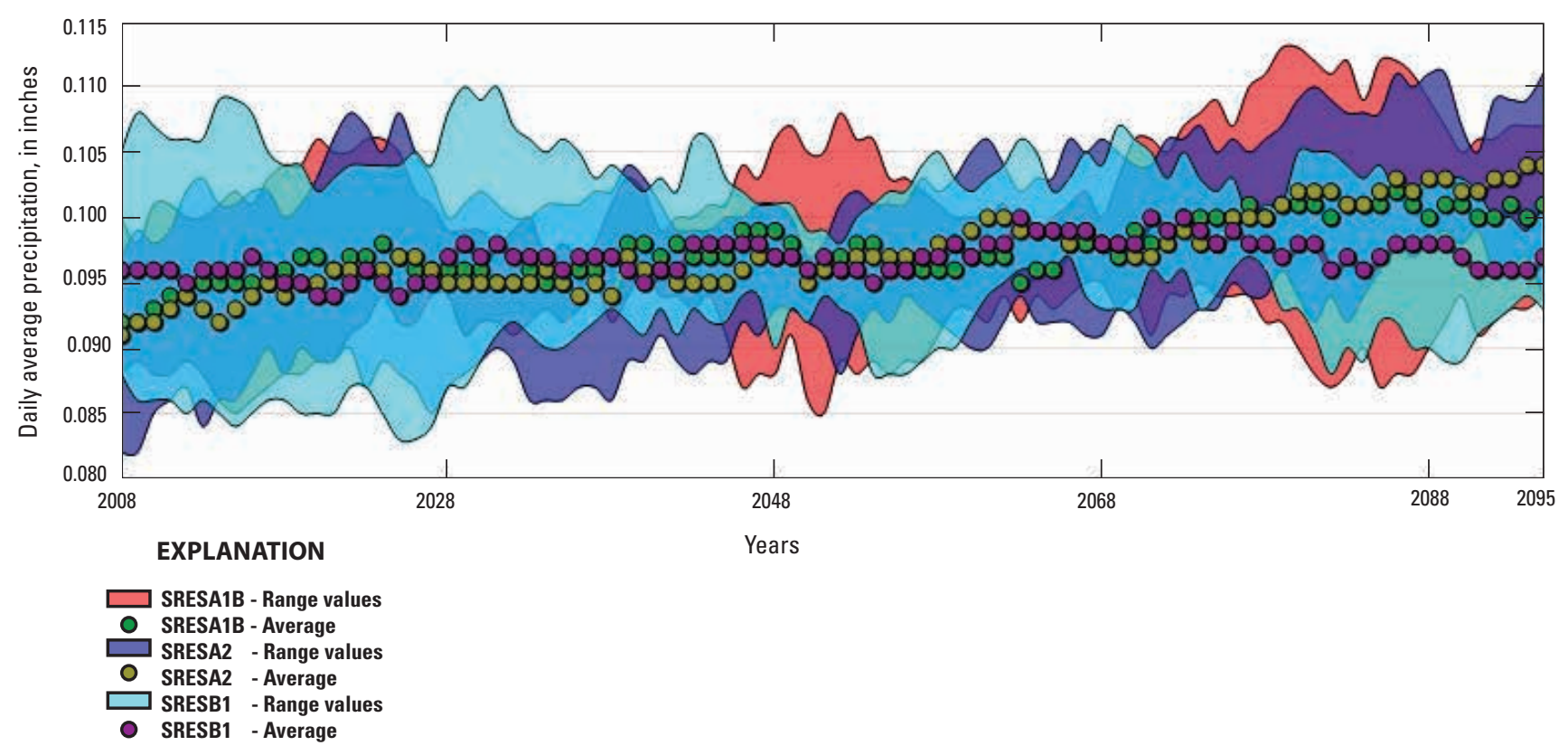

Figure 4. Range plot for PRMS variable daily average precipitation (basin_ppt) from 2008 to 2095 showing the central tendencies (averages) and annual mean ranges for five general circulation models and for three greenhouse gas emission scenarios for the Methow River basin, Washington.

\section{Output Data}

The PRMS model outputs for this project included simulated streamflow data for 13 streamflow-gaging stations and 10 area-weighted basin variables. Examples of this output are presented here as examples of the type of plots and data that are available online.

The change in the distribution of the snowpack snowwater equivalent (SWE) throughout the year in the basin is captured in the monthly boxplots for years 2030, 2060, and 2090 (fig. 5). SWE shows a pattern of decreased winter and spring snowpack over time, and is reflected in the monthly boxplots for streamflow (fig. 6). The decrease in SWE primarily is attributed to increasing air temperatures over time, resulting in more of the basin receiving precipitation as rain than as snow. The change in precipitation form translates to increased streamflow in the winter, as a greater percentage of winter precipitation in the future is rain that quickly becomes streamflow. Likewise, a decreased snowpack results in substantial decreases in spring streamflow. This trend of decreased future spring streamflows continues into the summer and early autumn when irrigation demand is highest (fig. 6). This potential pattern of the flow redistribution illustrates how climate change may affect the hydrology in mountain river basins in the West, and is a trend most prominent in basins having a large percentage of their drainage area in the rain/ snow transition zone (Gleick, 1987; Jeton and others, 1996; Mastin, 2008; and Mastin and others, 2011).

For a third type of plot (line plot), all general circulation models show an increase in the average annual flow over time at both a small (80.2- $\mathrm{mi}^{2}$ drainage area) upper-basin site (segment_cfs 20, fig. 7A) and a site at the mouth of the basin $\left(1,772-\mathrm{mi}^{2}\right.$ drainage area, segment_cfs 204, fig. 7B).

The simulated results in these two line plots are from the SRESA2 greenhouse gas emission scenario, the greenhouse emission scenario showing the greatest increase in precipitation by 2095 of the three scenarios (fig. 4). These line plots seem consistent with the subtle pattern of simulated precipitation showing little change in the first half of the century and a large increase in precipitation during the second half of the century.

PRMS output from the different GCM simulations show a wide variation of central tendencies. For example, the line plot for the Methow River near Pateros (fig. 7B) has annual variations among the five GCMs of as much as $722 \mathrm{ft}^{3} / \mathrm{s}$, or a range of 21.0 percent, above the average of the five GCM values for that year, and 17.5 percent below the average. However, the general trend of the individual general circulation model line plots seems to be similar for all model lines. 


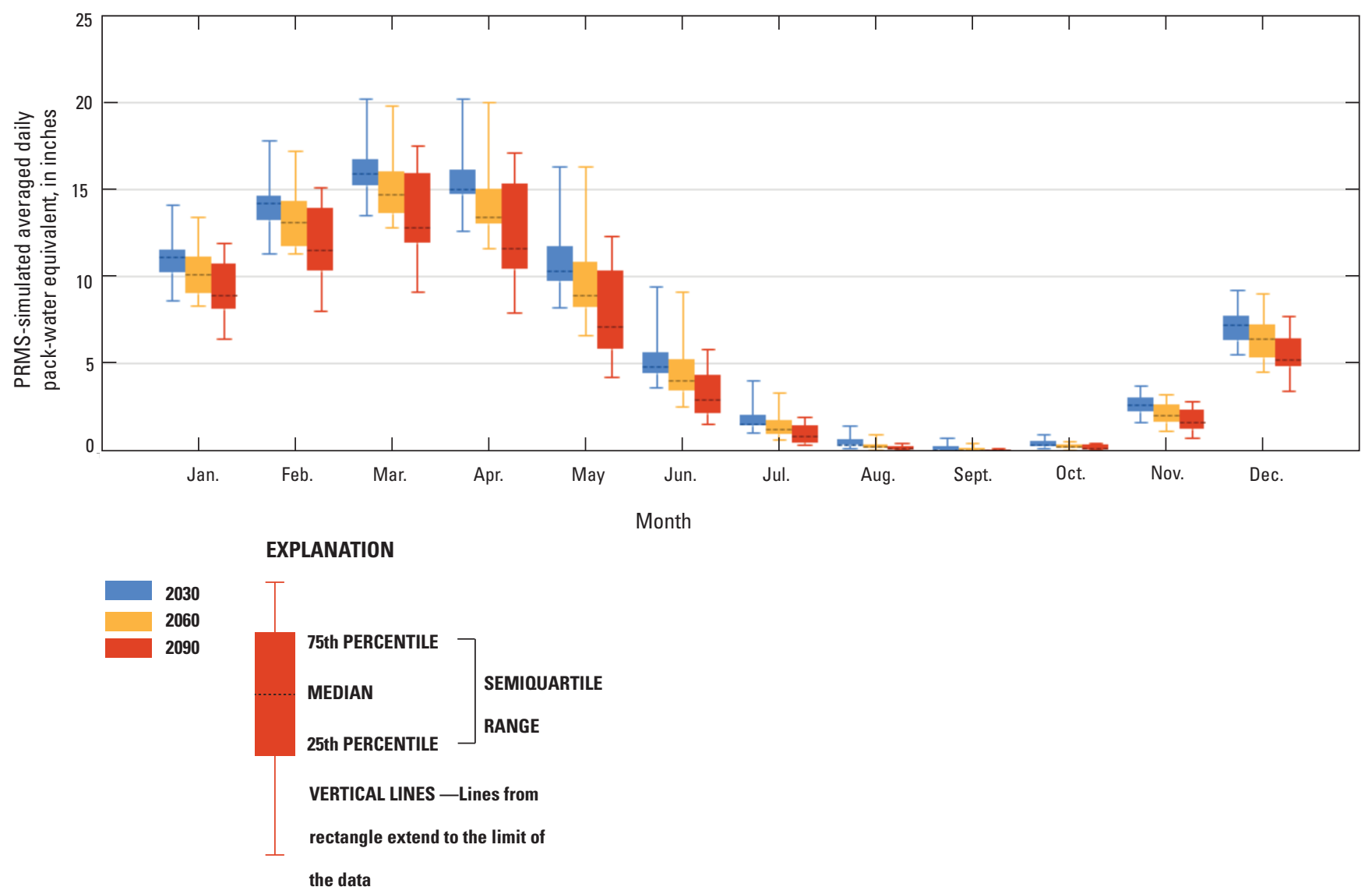

Figure 5. Boxplot for PRMS-simulated averaged daily pack-water equivalent (basin_pweqv) for the basin by month for all general circulation models and greenhouse gas emission scenarios for 11-year windows centered around years 2030, 2060, and 2090. 


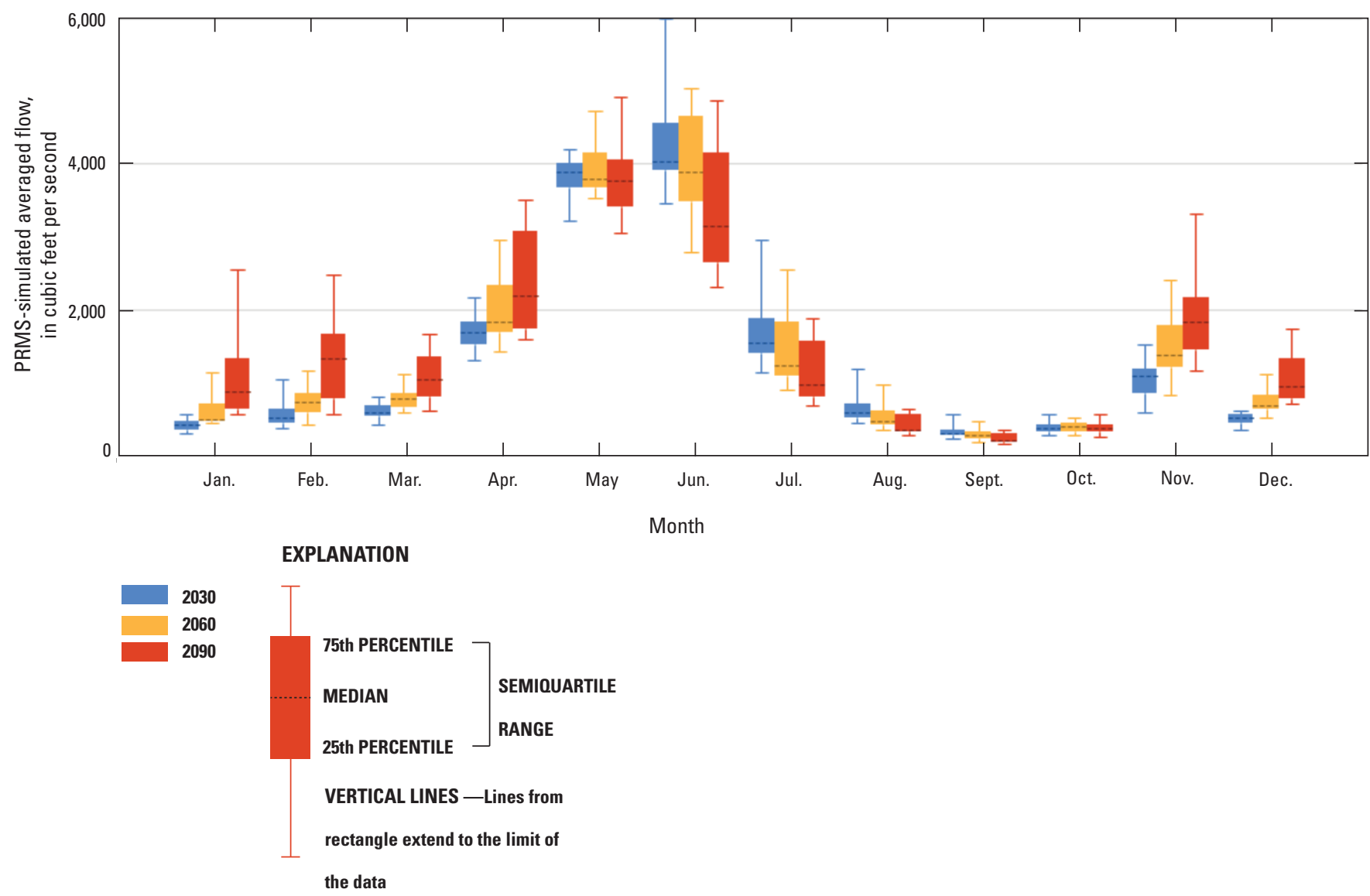

Figure 6. Boxplot for PRMS-simulated averaged flow on the Methow River at Winthrop, Washington (segment_cfs162) by month all general circulation models and greenhouse gas emission scenarios for 11-year windows centered around years 2030, 2060, and 2090. 


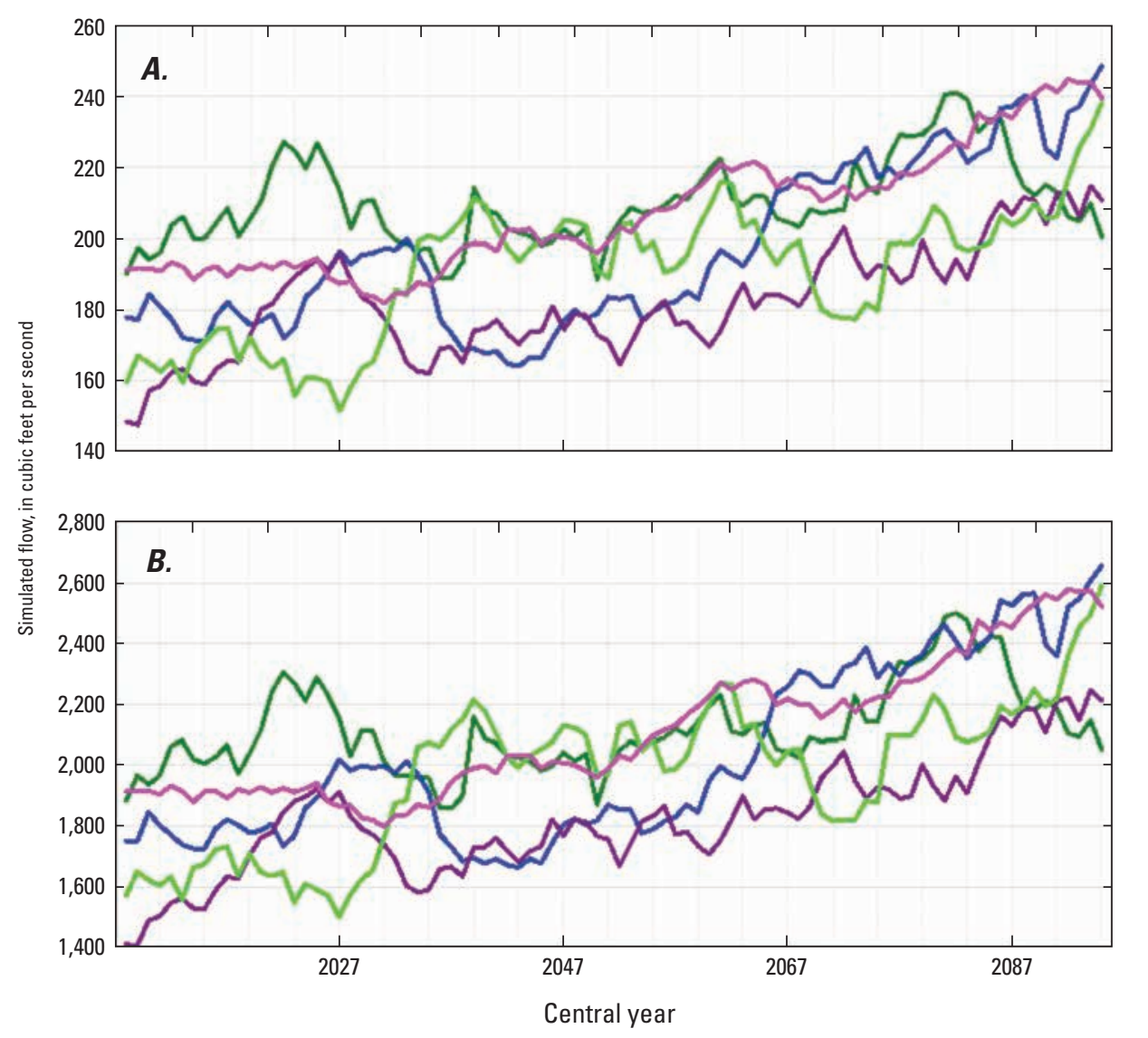

\section{EXPLANATION}

General circulation model.See table 1 for description of model

- BCCR_BCM2_0

- CSIRO_Mk3_0

- INMCM 3 _0

- MIROC3_2

Figure 7. Line plot for PRMS-simulated average flow for the five different general circulation models for the SRESA2 greenhouse gas emission scenario. (A) Early Winters Creek near Mazama, Washington (segment_cfs20); $(B)$ Methow River near Pateros (segment_cfs204).

\section{Web Site Features}

A new approach for providing public access to simulation data was developed and tested during this study. Our goal was to provide user-friendly interactive tools for exploring and retrieving data to help stakeholders with decision making. Another goal was to implement the recommendations in the USGS Scientific Strategy (U.S. Geological Survey, 2007) to leverage evolving technologies and to create accessible environments for data.

SQL Server 2008 R2 Reporting Services was used to generate five interactive reports (three chart reports, one data report, and one mapping report) for the project Web site. The reports access data from the same database that was used for managing model runs and processing simulation results. Data for the reports are accessed dynamically, providing the user with options for selecting variables of interest for time periods of their choosing.

\section{Line Charts}

A line chart plots the value of a selected variable for each of the five general circulation models over time for a selected greenhouse gas emission scenario. The line chart uses cascading variables (where the options available in a dropdown menu are dependent on options selected in a preceding drop-down menu) to form a query for retrieving data from the project database. For example, for the line chart report shown in figure 8, when a user selects a variable from the Variable drop-down menu, a query to the database is run that retrieves the names of all greenhouse gas emission scenarios associated with the selected parameter. The selected greenhouse gas emission scenario names are then used to populate the Scenario drop-down menu. A user then selects a greenhouse gas emission scenario from the Scenario drop-down menu and another query is run to find all years that have data for the selected greenhouse gas emission scenario. This databasedriven approach allows parameters, greenhouse gas emission scenarios, and years of data to be added or removed from the database without having to alter any of the code used to produce the line chart. 


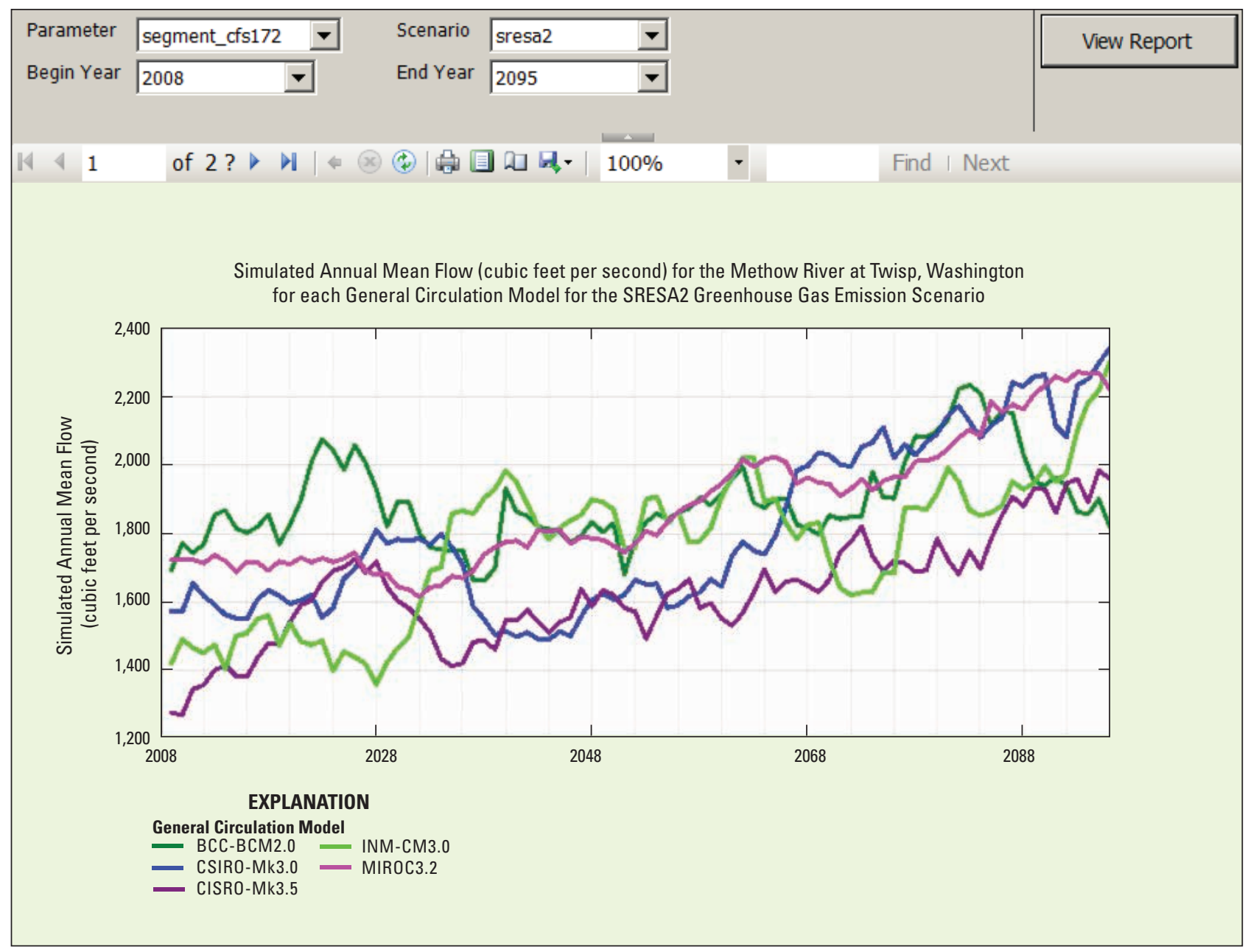

Figure 8. Example of the online line graph report for plotting the values of a selected variable for each of the five general circulation models over time for a selected greenhouse gas emission scenario.

\section{Range Graphs}

A range graph shows the selected variable over time. The "range" is a composite of the general circulation models represented in the line graphs for a given greenhouse gas emission scenario. The top, average, and bottom parts of the range represent the highest, average, and lowest of the five general circulation model 11-year window values, respectively (fig. 9).

\section{BoxPlots}

A single boxplot represents the distribution of simulated daily values for all general circulation models and greenhouse gas emission scenario combinations for a given month of the year. Three boxplots per month are plotted to show the relative change of the monthly distributions for the central years 2030, 2060, 2090. For example in figure 10, the distribution of daily flow values for Methow River at Twisp, Washington, during
June is distributed over a larger range in 2090 than in 2030 and the median value for flow is lower, whereas in October the distributions for 2030 and 2090 are similar.

\section{Data Reports}

The data report provides users with access to daily simulation results for all general circulation models over all greenhouse gas emission scenarios. For any model output parameter a user can download data in XML, TIFF, PDF, MHTML, Word, and Excel file formats for a specific greenhouse gas emission scenario and general circulation model for a selected time period as shown in figure 11.

\section{Web Maps}

The Web map report (fig. 12) shows the percent difference in flow between two user-selected years for all simulation sites in the Methow River basin for any greenhouse gas emission scenario and general circulation model combination. 


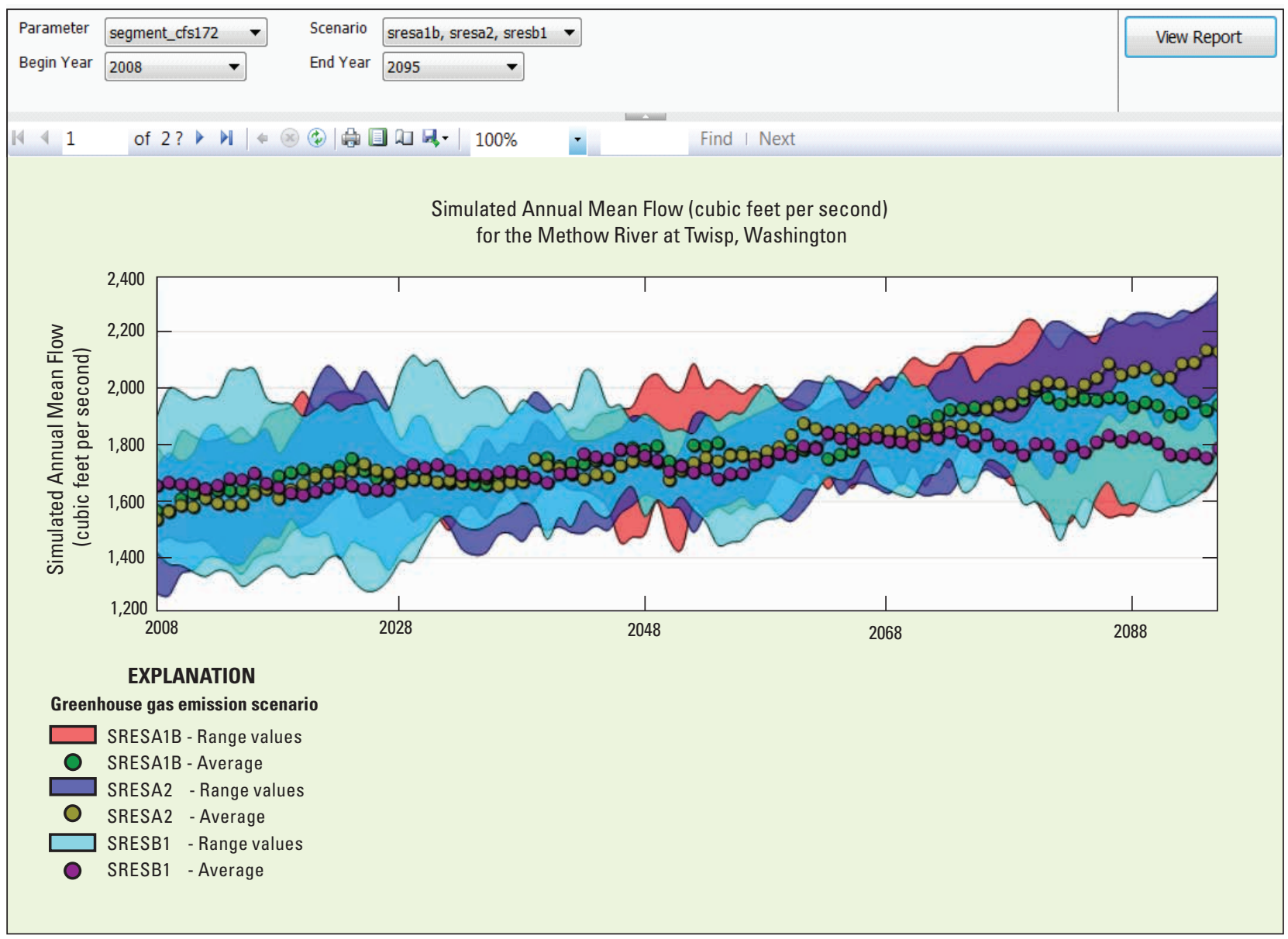

Figure 9. Example of the online range graph report for graphing selected variables over time. 


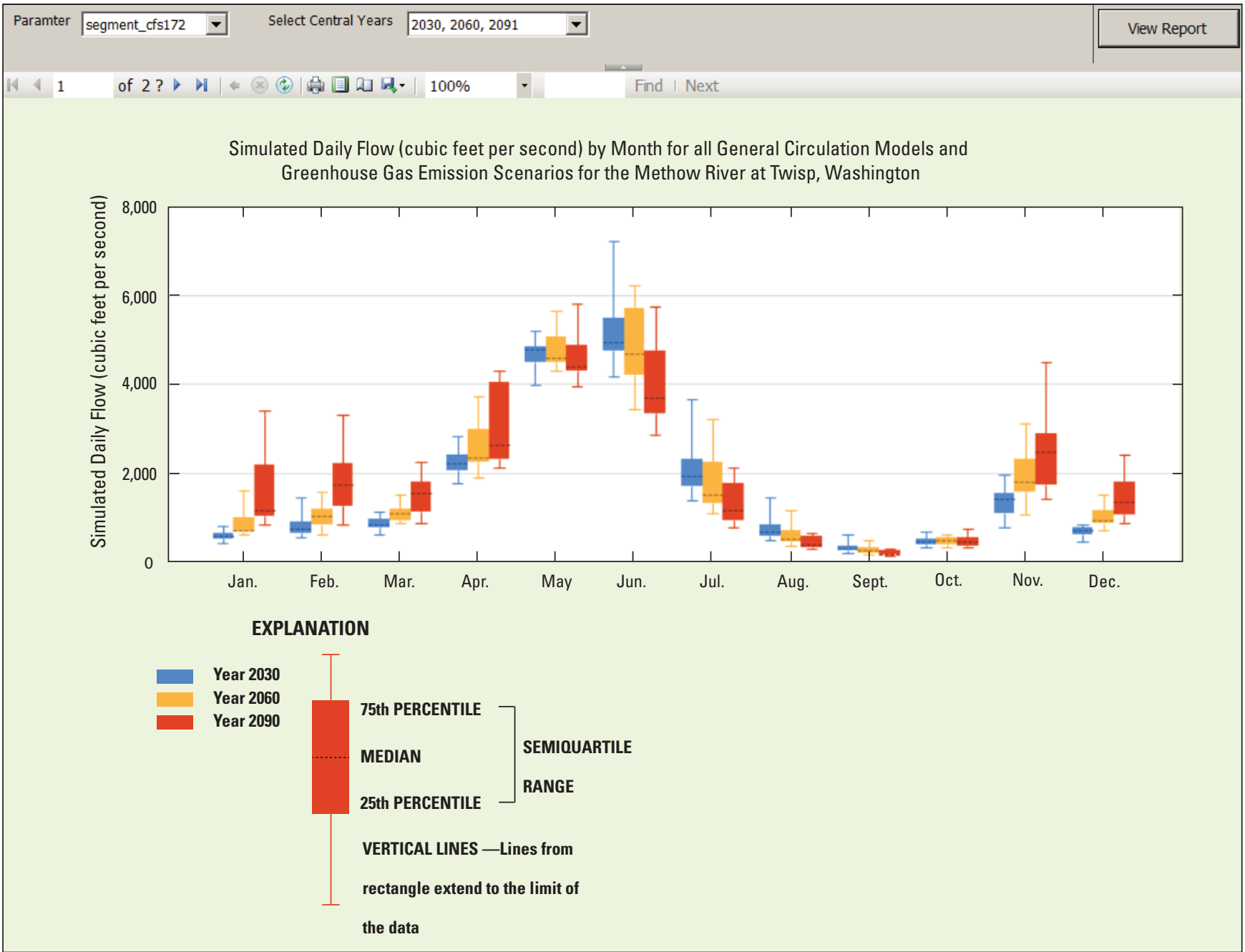

Figure 10. Example of the online boxplot report for generating boxplots representing the distribution of simulated daily values for all the general circulation models and greenhouse gas emission scenario combinations for a given month of the year.

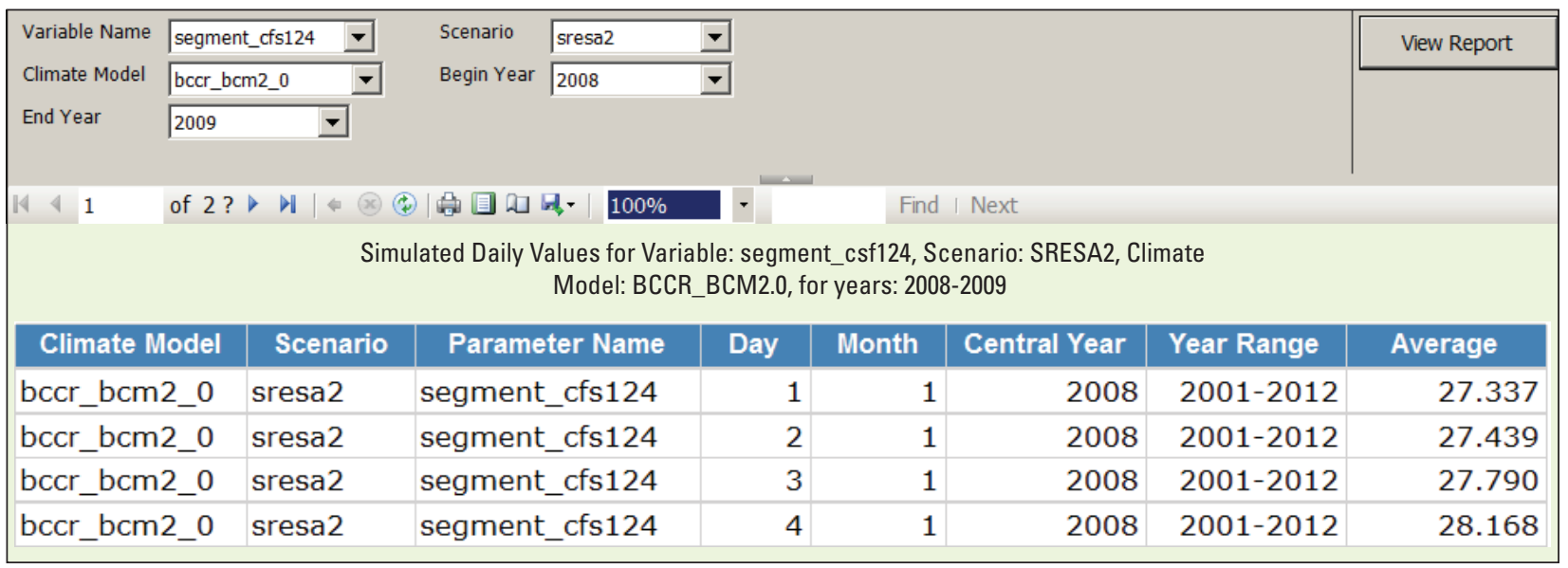

Figure 11. Example of the online data report for accessing daily values of simulation results for all general circulation models over all greenhouse gas emission scenarios. 


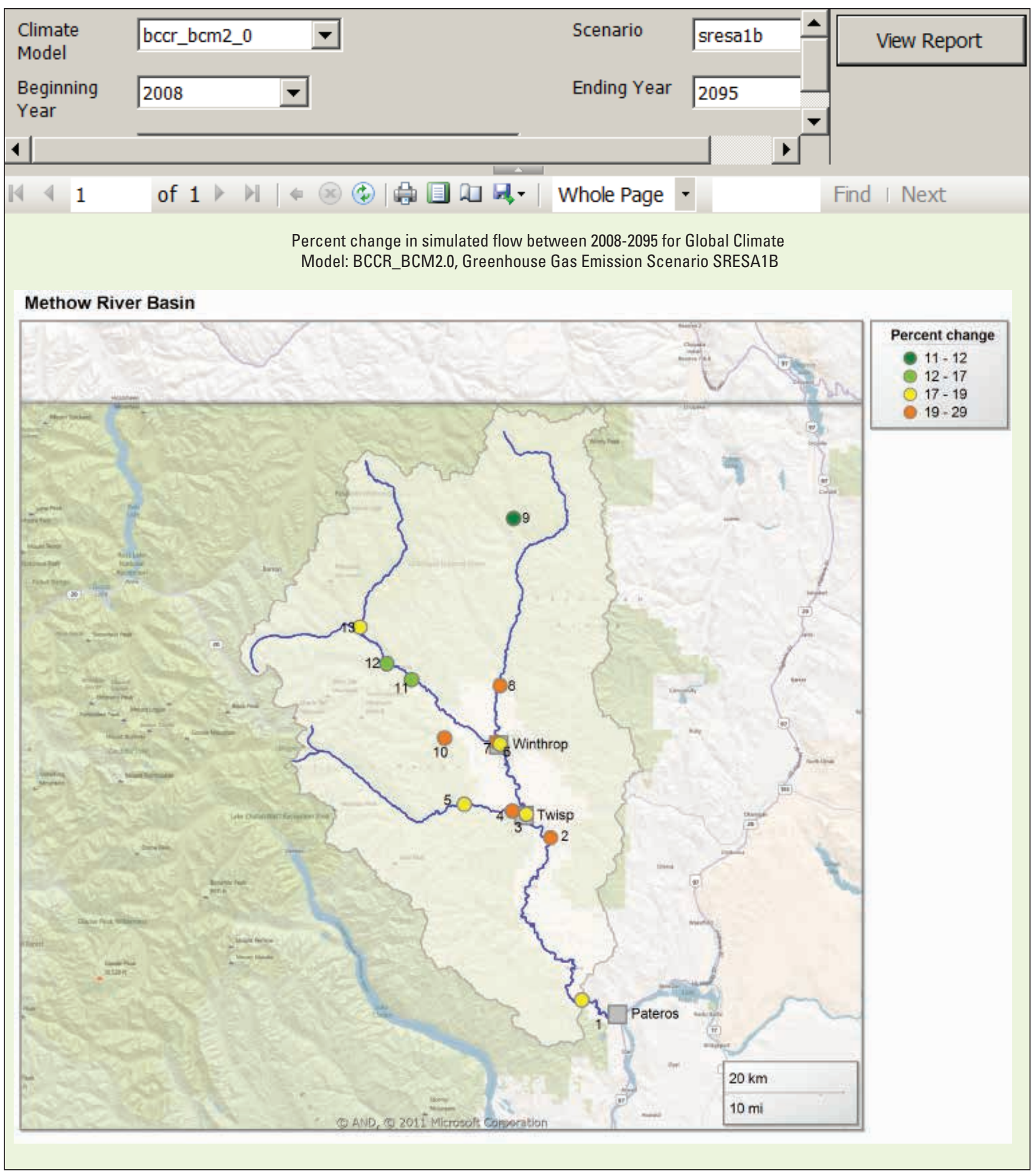

Figure 12. Example of the online map report for displaying percent difference in flow between two user-selected years for all simulation sites, for any greenhouse gas emission scenario and general circulation model combination. 


\section{Summary}

This project used existing general circulation model downscaling techniques to generate daily input climate time series to an existing watershed model for the Methow River basin in north-central Washington. Time series of simulated flow for 13 streamflow-gaging stations in the Methow River basin and time series for 10 basin-wide hydrologic variables were generated from combinations of five general circulation models and three greenhouse gas emission scenarios associated with the Intergovernmental Panel on Climate Change Fourth Assessment Report. An 11-year moving window of simulation results was used to estimate the effects of potential climate changes on the central tendencies of the hydrology of the basin for water years 2008-2095.

Results show a consistent increase in air temperature for all general circulation models and all greenhouse gas emission scenarios for the 88-year study period. Less evident is the change in precipitation over the basin. Averaged over the five general circulation models, simulated precipitation increased most notably when using the SRESA2 greenhouse gas emission scenario, particularly for the second half of the century, with no change from the first-year value to the last-year value for the SRESB1 greenhouse gas emission scenario. Annual simulated streamflow followed the pattern of precipitation. The most substantial change in streamflow is the redistribution of monthly streamflows. For all greenhouse gas emission scenarios, the future streamflows are greater in the winter than baseline conditions (water years 1990-2000) as a greater percentage of future precipitation falls as rain rather than as snow. In spring, future streamflows are less than baseline conditions because the spring snowpacks are smaller; and therefore, flow contributions from snowmelt are less.

A single relational database with integrated programming tools was used to store input and output data, automate simulations, process simulation results, and serve online data to stakeholders. The database-driven approach that was used minimized the need to perform manual operations of running the model, and thereby reduced user error, produced consistent results, and made operations easier. Online user-friendly interactive tools for exploring and retrieving data were developed to provide stakeholders a convenient method for accessing climate-change data for water-management decision making and planning.

\section{References Cited}

Daly, C., Neilson, R.P., and Phillips, D.L., 1994, A statisticaltopographic model for mapping climatological precipitation over mountainous terrain: Journal of Applied Meteorology, v. 33, p. 140-158.

Diaz-Nieto, J., and Wilby, R.L., 2005, A comparison of statistical downscaling and climate change factor methods-Impacts on low flows in the River Thames, United Kingdom: Climatic Change, v. 69, p. 245-268.

Ely, D.M., and Risley, J.C., 2001, Use of a precipitation-runoff model to simulate natural streamflow conditions in the Methow river Basin, Washington: U.S. Geological Survey Water-Resources Investigations Report 01-4198, 36 p. (Also available at http://pubs.usgs.gov/wri/wri014198/.)

Ely, D.M., 2003, Precipitation-runoff simulations of current and natural streamflow conditions in the Methow River Basin, Washington: U.S. Geological Survey WaterResources Investigations Report 03-4246, 35 p. (Also available at http://pubs.usgs.gov/wri/wri034246/.)

Gleick, P.H., 1987, Regional hydrologic consequences of increases in atmospheric $\mathrm{CO}_{2}$ and other trace gages: Climatic Change, v. 10, no. 2, p. 137-161.

Hamlet, A.F., Carrasco, J., Deems, J., Elsner, M.M., Kamstra, T., Lee, C., Lee, S.Y., Mauger, G., Salathe, E.P., Tohver, I., Whitely Binder, L., 2010, Final project report for the Columbia River Basin Climate Change Scenarios Project: Climate Impacts Group, accessed January 10, 2012, at http://www.hydro.washington.edu/2860/.

Hay, L.E., Markstrom, S.L., and Ward-Garrison, C., 2011, Watershed-scale response to climate change through the twenty-first century for selected basins across the United States: Earth Intractions, v. 15, p. 1-37.

Hay, L.E., Wilby, R.L., and Leavesley, G.H., 2000, A comparison of delta change and downscaled SRES emission scenarios for three mountainous basins in the United States: Journal of American Water Resources, v. 36, no. 2, p. 387-397. 
Intergovernmental Panel on Climate Change, 2007, Summary for policymakers, in climate change 2007-The physical science basis, Contributions of Working Group 1 to the Fourth Assessment Report of the Intergovernmental Panel on Climate Change: Cambridge and New York, Cambridge University Press, 18 p., accessed January 10, 2012, at http:// www.ipcc.ch/publications and data/ar4/wg3/en/ch3s3-1. $\underline{\text { html. }}$

Jeton, A.E., Dettinger, M.D., and Smithe, J.L., 1996, Potential effects of climate change on streamflow, eastern and western slopes of the Sierra Nevada, California and Nevada: U.S. Geological Survey Water-Resources Investigations Report 95-4260, 49 p. (Also available at http://pubs.er.usgs. gov/publication/wri954260.)

Kiker, G.A., Bridges, T.S., Varghese, A., Seager, T.P., and Linkov, I., 2005, Application of multicriteria decision analysis in environmental decision making: Integrated Environmental Assessment and Management, v. 1, no. 2, p. 95-108.

Konrad, C.P., Drost, B.W., and Wagner, R.J., 2003, Hydrogeology of the unconsolidated sediments, water quality, and ground-water/surface-water exchanges in the Methow River Basin, Okanogan County, Washington: U.S. Geological Survey Water-Resources Investigations Report 03-4244, 137 p. (Also available at http://pubs.usgs.gov/wri/ wri034244/.)

Leavesley, G.H., Lichty, R.W., Troutman, B.M., and Saindon, L.G., 1983, Precipitation-runoff modeling system-User's manual: U.S. Geological Survey Water-Resources Investigations Report 83-4238, 207 p. (Also available at http://pubs.er.usgs.gov/publication/wri834238.)

Leavesley, G.H., Restrepo, P.J., Markstrom, S.L., Dixon, M., and Stannard, L.G., 1996, The modular modeling system (MMS) - User's manual: U.S. Geological Survey Open-File Report 96-151, 200 p.

Markstrom, S.L., Niswonger, R.G., Regan, R.S., Prudic, D.E., and Barlow, P.M., 2008, GSFLOW-Coupled ground-water and surface-water flow model based on the integration of the Precipitation — runoff modeling system (PRMS) and the modular ground-water flow model (MODFLOW-2005): U.S. Geological Survey Techniques and Methods 6-D1, 240 p. (Also available at http://pubs.usgs.gov/tm/tm6d1/.)
Mastin, M.C., 2008, Effects of potential future warming on runoff in the Yakima River basin, Washington: U.S. Geological Survey Science Investigations Report 20085124, 12 p. (Also available at http://pubs.usgs.gov/ $\underline{\operatorname{sir} / 2008 / 5124 / .)}$

Mastin, M.C., Chase, K. J., and Dudley, R.W., 2011, Changes in spring snowpack for selected basins in the United States for different climate-change scenarios: Earth Interactions,v. 15, no. 23, p. 1-18, accessed January 10, 2012, at http:// journals.ametsoc.org/doi/abs/10.1175/2010EI368.1.

McCabe, G.J., and B.M., Wolock, 1997, Climate change and the detection of trends in annual runoff: Climate Research, v. 8, p. 129-134.

Methow Basin Planning, 2005, Methow Basin (WRIA 48) Watershed Plan: Methow Basin Planning Unit, 50 p., accessed January 10, 2012, at http://okanogancounty.org/ water/Documents\%20on\%20Site/Methow\%20Basin\%20 plan\%20text.pdf.

U.S. Geological Survey, 2007, Facing tomorrow's challenges-U.S. Geological Survey science in the decade 2007-2017: U.S. Geological Survey Circular 1309, 81 p. (Also available at http://pubs.usgs.gov/circ/2007/1309/).

U.S. Geological Survey, 2011, StreamStats: U.S. Geological Survey, accessed January 10, 2012, at http://water.usgs.gov/ osw/streamstats/Washington.html.

Viger, R.J., Markstrom, S.L., and Leavesley, G.H., 1998, The GIS Weasel-An interface for the treatment of spatial information used in watershed modeling and water resource management, in First Federal Interagency hydrologic Modeling Conference, First, Las Vegas, Nevada, April 19-23, 1998, Proceedings: Las Vegas, Nevada, Interagency Advisory Committee on Water Data, v. 2, chap. 7, p. 73-80. 
Publishing support provided by the U.S. Geological Survey

Publishing Network, Tacoma Publishing Service Center

For more information concerning the research in this report, contact the

Director, Washington Water Science Center

U.S. Geological Survey

934 Broadway, Suite 300

Tacoma, Washington 98402

http://wa.water.usgs.gov 
